Review

\title{
Phycocyanin: A Potential Drug for Cancer Treatment
}

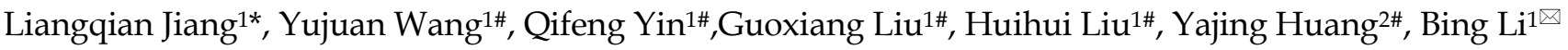 \\ 1. Department of Genetics and Cell Biology, Basic medical college, 308 Ningxia Road, Qingdao University, Qingdao, China, 266071; \\ 2. Basic medical college, 308 Ningxia Road, Qingdao University, Qingdao, China, 266071. \\ * The first author: Liangqian Jiang Email: jiang8014@163.com \\ \# Contributed equally \\ $\square$ Corresponding author: Professor Bing Li, Department of Genetics and Cell Biology, Basic medical college, 308 Ningxia Road, Qingdao University, Qingdao, \\ China, 266071. Tel: 86-532-83780060 Email: libing_516619@163.com \\ (c) Ivyspring International Publisher. This is an open access article distributed under the terms of the Creative Commons Attribution (CC BY-NC) license \\ (https:// creativecommons.org/licenses/by-nc/4.0/). See http://ivyspring.com/terms for full terms and conditions.
}

Received: 2017.05.17; Accepted: 2017.08.30; Published: 2017.09.20

\begin{abstract}
Phycocyanin isolated from marine organisms has the characteristics of high efficiency and low toxicity, and it can be used as a functional food. It has been reported that phycocyanin has anti-oxidative function, anti-inflammatory activity, anti-cancer function, immune enhancement function, liver and kidney protection pharmacological effects. Thus, phycocyanin has an important development and utilization as a potential drug, and phycocyanin has become a new hot spot in the field of drug research. So far, there are more and more studies have shown that phycocyanin has the anti-cancer effect, which can block the proliferation of cancer cells and kill cancer cells. Phycocyanin exerts anti-cancer activity by blocking tumor cell cell cycle, inducing tumor cell apoptosis and autophagy, thereby phycocyanin can serve as a promising anti-cancer agent. This review discusses the therapeutic use of phycocyanin and focuses on the latest advances of phycocyanin as a promising anti-cancer drug.
\end{abstract}

Key words: Phycocyanin, Apoptosis, Autophagy, Cancer, Cell cycle arrest.

\section{Introduction: Phycocyanin}

In the past few decades, natural products have become increasingly important for the application of chemical prevention and treatment for diseases [1]. Natural products derived from food or food supplements could be used as drugs in the treatment for diseases, and their chemical prevention and chemotherapy effects have been fully studied [2,3]. Recently, marine natural products with pharmacological activity have been shown to have potent anti-cancer activity, and have less or no toxic side effects [4]. Thus, marine natural products have an important development and utilization in recent years. In addition, marine natural products have become one of the most important resources of novel lead compounds for critical diseases. Phycocyanin (PC), a marine natural extract, has been studied for its anti-cancer effect on malignant solid tumors [5]. In addition, phycocyanin is a toxin on cancer cells while it is non-toxic to normal cells [6].
Phycocyanin is a biologically active nutrient compound which is isolated and purified from a variety of seaweeds [7]. Phycocyanin obtained from different species, such as Aphanizomenon sp. [8], Spirulina sp. [9], Phormidium sp. [10], Lyngbya sp. [11], Synechocystis sp. [12] and Synechococcus sp. [13], has been separated and studied.

Phycocyanin belongs to the phycobiliprotein (PBP) family [14], which is characterized by a deep and intense blue color. According to the colored molecules, phycobiliproteins can be divided into three categories: phycoerythrin (PE, PE is red), phycocyanin (PC, PC is blue), and allophycocyanin (AP, AP is bluish green) $[15,16]$.

Phycocyanin is a kind of photosynthetic assistant protein which can efficiently capture light energy [17]. Phycobiliprotein is one of the components of phycobilisome [15], which is a supramolecular protein complex that auxiliarily collects light energy. 
Phycobilisome plays an important role in photosynthesis energy absorption and transmission [18]. Phycobiliprotein acts as an antenna molecule in algae photosynthesis, which can absorb light energy and can be capable of efficiently delivering light energy to a reaction center containing chlorophyll by a non-radioactive process [19].

\section{Phycocyanin: General properties}

Phycocyanin has a deep and intense blue color and consists of $\alpha$ and $\beta$ subunits [20]. In general, the $\alpha$ and $\beta$ subunits of the phycocyanin form a stable heterodimeric monomer $(\alpha \beta)$ and then polymerize it into a multimer $(\alpha \beta) n \quad(n=1 \sim 6)$ [21]. Most phycocyanins are present as a trimer $(\alpha \beta)_{3}$. The $\alpha$ and $\beta$ subunits of C-phycocyanin have similar 3D structures; however, their sequences are different [22]. The $\alpha$ and $\beta$ subunits contain about 160 to 180 amino acid residues, respectively. The molecular weight of $a$ and $\beta$ subunits ranges $10 \sim 19 \mathrm{kD}$ and $14 \sim 21 \mathrm{kD}$, and the ratio of $\alpha$ and $\beta$ subunits is usually $1: 1$. Each subunit is linked to $1 \sim 4$ chromophores, so that phycobiliproteins have a specific absorption spectrum [23-25]. The amino acid sequences of $\alpha$ and $\beta$ subunits from Spirulina platensisis were just as follows (table 1):

Table 1. The amino acid sequences of $\alpha$ and $\beta$ subunits of C-PC from Spirulina platensisis

\begin{tabular}{ll}
\hline$\alpha$ chain & $\beta$ chain \\
\hline MKTPLTEAVSIADSQGRFLS & MFDAFTKVVSQADTRGEMLS \\
STEIQVAFGRFRQAKAGLEA & TAQIDALSQMVAESNKRLDA \\
AKALTSKADSLISGAAQAVY & VNRITSNASTIVSNAARSLF \\
NKFPYTTQMQGPNYAADQRG & AEQPQLIAPGGNAYTSRRMA \\
KDKCARDIGYYLRMVTYCLI & ACLRDMEIILRYVTYAVFAG \\
AGGTGPMDEYLIAGIDEINR & DASVLEDRCLNGLRETYLAL \\
TFELSPSWYIEALKYIKANH & GTPGSSVAVGVGKMKEAALA \\
GLSGDAATEANSYLDYAINA & IVNDPAGITPGDCSALASEI \\
LS & ASYFDRACAAVS \\
\hline
\end{tabular}

The amino acid sequence of C-phycocyanin is gotten from the Protein Database of the United States Research Collaboratory for Structural Bioinformatics (RCSB PDB, http:/ / www.rcsb.org).

Each polypeptide chain of phycocyanin consists of apoprotein and chromophore with a ring-opening tetrapyrrole structure. The chromophore in phycobiliprotein is called phycobiliin. Phycocyanin contains for phycocyanobilin (PCB) chromophores, and the $\mathrm{PCB}$ chromophores span an absorption range from 590 to $670 \mathrm{~nm}$ [21].

At present, there are a variety of phycocyanins to obtain high purity crystals, and the high-resolution X-ray crystallography was used to determine the high-level structure. The Protein Database of the United States Research Collaboratory for Structural
Bioinformatics (RCSB PDB, http://www.rcsb.org) has included more than 20 advanced structures of phycocyanins (Table 2).

The isoelectric point of phycocyanin is between 4.1 and 6.4, depending on the source of extraction and the method of extraction and purification [42, 43]. Recent research suggests that phycocyanin is light sensitive, so phycocyanin must be preserved in the dark [43]. Since phycocyanin is sensitive to heat [44, $45]$, phycocyanin must be purified at $4 \sim 5{ }^{\circ} \mathrm{C}[46,47]$.

Table 2. Three-dimensional structures of phycocyanins in RCSB PDB

\begin{tabular}{lllll}
\hline PDB ID & Type & Source & Resolution & Ref. \\
\hline 5TOU & C-Phycocyanin & Pseudanabaena sp. lw0831 & $2.04 \AA$ & {$[26]$} \\
4ZIZ & C-Phycocyanin & Thermosynechococcus elongatus & $1.75 \AA$ & {$[27]$} \\
4Z8K & C-Phycocyanin & Thermosynechococcus elongatus & $2.5 \AA$ & {$[28]$} \\
4L1E & C-Phycocyanin & Leptolyngbya sp. N62DM & $2.61 \AA$ & {$[29]$} \\
4N6S & C-Phycocyanin & Thermosynechococcus vulcanus & $2.4 \AA$ & {$[30]$} \\
4F0T & C-Phycocyanin & Synechocystis sp. PCC 6803 & $2.61 \AA$ & {$[31]$} \\
4GXE & C-Phycocyanin & Thermosynechococcus vulcanus & $3.0 \AA$ & {$[31]$} \\
4GY3 & C-Phycocyanin & Thermosynechococcus vulcanus & $2.5 \AA$ & {$[31]$} \\
4H0M & C-Phycocyanin & Synechococcus elongatus & $2.2 \AA$ & {$[31]$} \\
3O18 & C-Phycocyanin & Thermosynechococcus vulcanus & $1.35 \AA$ & {$[32]$} \\
3O2C & C-Phycocyanin & Thermosynechococcus vulcanus & $1.5 \AA$ & {$[32]$} \\
2BV8 & C-Phycocyanin & Gracilaria chilensis & $2.01 \AA$ & {$[33]$} \\
1ON7 & C-Phycocyanin & Thermosynechococcus vulcanus & $2.7 \AA$ & {$[20]$} \\
1JBO & C-Phycocyanin & Synechococcus elongatus & $1.45 \AA$ & {$[34]$} \\
1HA7 & C-Phycocyanin & Arthrospira platensis & $2.2 \AA$ & {$[35]$} \\
1KTP & C-Phycocyanin & Thermosynechococcus vulcanus & $1.6 \AA$ & {$[36]$} \\
1F99 & R-Phycocyanin & Polysiphonia urceolata & $2.4 \AA$ & {$[37]$} \\
1I7Y & C-Phycocyanin & Thermosynechococcus vulcanus & $2.5 \AA$ & {$[38]$} \\
1PHN & C-Phycocyanin & Cyanidium caldarium & $1.65 \AA$ & {$[39]$} \\
1CPC & C-Phycocyanin & Microchaete diplosiphon & $1.66 \AA$ & {$[40]$} \\
1GHO & C-Phycocyanin & Arthrospira platensis & $2.2 \AA$ & {$[41]$} \\
\hline & & & & \\
\hline
\end{tabular}

\section{Isolation and Purification}

So far, phycocyanins are isolated from algae in all studies. Purification involves multiple steps of crude extraction, including extraction with ammonium sulfate and separation on an ion exchange column [48], hydroxyapatite column [8] or gel filtration chromatography [49].

The determination of phycocyanin purity is based on the absorbance ratio $\mathrm{A}_{620} / \mathrm{A}_{280}$, and the absorbance at 620 and $280 \mathrm{~nm}$ corresponds to phycocyanin and total protein, respectively [50]. When $\mathrm{A}_{620} / \mathrm{A}_{280} \leq 0.7$, phycocyanin is considered to be food grade, when $0.7 \leq \mathrm{A}_{620} / \mathrm{A}_{280} \leq 3.9$, phycocyanin is considered to be reagent grade, when $\mathrm{A}_{620} / \mathrm{A}_{280} \geq 4.0$, phycocyanin is considered to be analysis level [51,52]. Similarly, the phycocyanin concentration can be calculated based on the absorbance values of $\mathrm{A}_{620}$ and $A_{652}$ which corresponds to the allophycocyanin [42, 48]. The formula is as follows:

$$
\begin{gathered}
C-P C(\mathrm{mg} / \mathrm{ml})=\left(\mathrm{A}_{620 \mathrm{~nm}}-0.474 \mathrm{~A}_{652 \mathrm{~nm}}\right) / 5.34 \\
\text { Purity }=\mathrm{A}_{620} / \mathrm{A}_{280}
\end{gathered}
$$




\section{Clinical uses of phycocyanin}

Phycocyanin can have a potent potential as a drug in a wide range of clinical applications. Phycocyanin shows a wide range of pharmacological effects, with anti-oxidation [53], anti-cancer [54], anti-inflammatory activity [55], photo-induced cytotoxicity [56] and stimulating the immune system [57].

Phycocyanin plays an antioxidant role in inhibiting hepatic lipid peroxidation and being helpful to liver protection $[58,59]$. Phycocyanin also scavenges free radicals from damaged nerve cells, which could avoid DNA oxidative damage cause from free radicals and prevent neuronal cell apoptosis $[60,61]$. There are more and more researches have shown that phycocyanin plays an effective anti-cancer role in various cancer cell types (such as breast cancer [57, 62], liver cancer [63], lung cancer[64, 65], colon cancer [66], Leukemia [67] and bone marrow cancer [68] and so on) in vitro and in vivo. Morcos first discovered the laser-induced cytotoxicity of phycocyanin, which could kill tumor cells, while the damage to normal tissue is minimal [69]. When in combination with He-Ne light, C-phycocyanin can serve as a photosensitize agent in the photodynamic therapy, which could provide a possible tumor therapy [57]. C-phycocyanin shows specific affinity to the scavenger receptor-A (SR-A) of tumor-associated macrophages (TAMs), which is highly expressed on TAM. Thus, C-phycocyanin can act as a new class of TAM-targeted photosensitiser, which exhibits an efficient in vitro photodynamic activity, and selectively accumulates in tumour sites probably due to the affinity to TAM, which provides a novel strategy to enhance the efficacy for cancer therapy [70]. Moreover, C-phycocyanin displays an anti-inflammatory potential, so C-phycocyanin is a potential natural anti-inflammatory agent [71, 72]. Phycocyanin can promote animal blood cell regeneration, improve lymphocyte activity and lymphatic system to improve immune function, and comprehensively enhance the disease resistance of the body [73]. In addition, C-phycocyanin could inhibit TGF- $\beta 1$-induced EMT and C-PC might be a potential anti-fibrosis drug [74].

\section{Molecular targets of phycocyanin}

Phycocyanin can affect cancer cell cycle progression, leading to cell cycle arrest. Cell cycle arrest in G0/G1 phase was described in breast cancer MDA-MB-231 [6], colon cancer HT29 and adenocarcinoma A549 cells [54]. Phycocyanin could increase the expression of p21, meanwhile, Phycocyanin could down-regulate the expression of Cyclin E and CDK2 in the MDA-MB-231 cells [6].
Phycocyanin is able to activate the apoptotic pathway (the mitochondrial/ cytochrome C pathway), activate caspase and induce poly (ADP-ribose) polymerase-1 (PARP-1) cleavage, alter the $\mathrm{Bcl}-2 / \mathrm{Bax}$ ratio (Bcl-2/Bax ratio represents apoptosis degree) [67]. In addition, phycocyanin can alter the mitochondrial membrane potential (MMP) [62], which can stimulate the release of cytochrome c and promote the formation of reactive oxygen species (ROS), ultimately lead to cancer cell apoptosis [75].

Phycocyanin can promote the expression of CD59 protein and Fas protein in Hela cells, While Phycocyanin had no significant effect on CD59 and Fas protein expression in normal $\mathrm{CHO}$ cells [76]. C-phycocyanin can down-regulate the expression of pro-inflammatory cytokines (IL-1 $\beta$, IL-2, interferon- $\gamma$ and tumor necrosis factor- $\alpha$ ), transcription factors (Janus kinase 3 (Jak3), signal transducers and activators of transcription 3(stat3)), and enhance the expression of anti-inflammatory cytokines IL-4 [77]. Phycocyanin can inhibit the expression of COX-2 and prostaglandin E2 (PGE2), and down-regulate the MMP-9 expression by mitogen-activated protein kinase (MAPK) signaling pathway [6]. C-phycocyanin from Spirulina platensis could inhibit MMP-2 and MMP-9 expression and TIMP-2 at a mRNA expression level; however, C-phycocyanin could not have any effect on MMP-1 expressed in MDA-MB231 and TIMP-1 expressed in HepG2 cells [78]. In addition, C-phycocyanin could bind to VEGFR1 alone, and down-regulated levels of VEGF-A, MMP-2 and MMP-9 [79].

The anti- proliferation effect of phycocyanin is mediated by BCR-ABL signaling and inactivation of the downstream PI3K/Akt pathway [80]. In addition, MAPK, PI3K/Akt/mTOR and NF-kB pathways involved phycocyanin-induced cell death [81].

C-phycocyanin could down-regulate the expression of vimentin, type 1 collagen and fibronectin, and up-regulating the expression of E-cadherinin in TGF- $\beta 1$-treated cells. Thus, C-phycocyanin C could inhibit EpithelialMesenchymal Transition (EMT) [74].

In addition, C-phycocyanin shows specific affinity to the scavenger receptor-A (SR-A) of tumour-associated macrophages (TAMs) [70]. C-PC inhibits the expression of MDR1 in a reactive oxygen species and COX-2 dependent manner in HepG2 cells. Further, C-PC inhibits NF-KB and AP-1 mediated signal transduction pathways which involved in the regulation of MDR1 expression [82].

\section{Phycocyanin and cancer}

Cancer is a generic term for malignancy diseases, their basic characteristics are cell proliferation and 
apoptosis out of control, and hyperplasia to form a new organism (neoplasm). The pharmacological effects of anti-cancer drugs generally include inhibition of tumor cell proliferation, induction of tumor cell apoptosis, cell cycle arrest and inhibition of tumor cell metastasis and so on. In fact, most drugs with anti-cancer properties are derived from natural compounds [83]. Among them, phycocyanin, a marine drug, plays an anti-proliferation and pro-apoptotic effects on different cancer cell lines in vitro, while phycocyanin have no side effects on normal tissue cells [84, 85]. More and more evidences have proved that phycocyanin has an effective anti-cancer effect on various cancer cell types (such as breast cancer [57, 62], liver cancer [63], lung cancer [64, 65], colon cancer [66], Leukemia [67] and bone marrow cancer [68]) in vitro and in vivo. High-dose phycocyanin does not induce significant toxic symptoms or mortality in animal experiments $[81,86]$. These studies demonstrated the therapeutic potential of phycocyanin in cancer therapy.

\section{Cell cycle arrest}

Cell cycle regulation plays an important role in cell proliferation, differentiation and apoptosis. In recent years, it has been reported that cell cycle regulation dysfunction is closely related to the development of tumor. Thus, pharmacological interventions for cell cycle are becoming a potential pathway for tumor therapy. Normal cell cycle is controllable while tumor cell cycle is out of control, thus tumor cells can infinitely proliferate. So it is particularly important that how to regulate cell cycle in tumor therapy.

The cell cycle is divided into two phases: interphase and division phase. The interphase includes G1 phase, S phase and G2 phase. The cell cycle includes three major cell cycle checkpoints: the G1 / S detection point, the S phase detection point, and the G2 / M detection point, which are the critical steps for the cell cycle. Cell cycle checkpoints are the most significant targets for many anticancer drugs, which further induce tumor cell apoptosis by blocking these checkpoints.

When C-PC treated tumor cells HT-29 and A549, it was reported that cell cycle was blocked in the cell cycle G0 / G1 phase, DNA synthesis was blocked, thus, tumor cell proliferation was inhibited [54]. Similarly, when C-PC treated human breast tumor cell MDA-MB-231 and human squamous carcinoma cell 686LN-M4C1, these tumor cells were found to have different degrees of cell cycle arrest in G0 / G1 phase $[6,66]$. Phycocyanin could increase the expression of p21, meanwhile, Phycocyanin could down-regulate the expression of Cyclin E and CDK2 in the
MDA-MB-231 cell [6].Moreover, phycocyanin could prevent $\mathrm{K} 562$ cells into $\mathrm{S}$ phase and the cells were arrested in G1 phase [87].

In addition, Gaoyong Liao found that phycocyanin blocked G2 / M cell cycle progression and induced apoptosis of PANC-1 cells [81]. Jun Ying proved that phycocyanin led to G2 / M phase arrest of SKOV-3 cells [88]. Chunyan Wang also confirmed that phycocyanin caused cell cycle G2 / M arrest and induced apoptosis in human hepatoma cell line HepG2 [56]. It was interesting to note that several groups reported the mechanism of PC-mediated cell cycle arrest (Table 3 ).

Table 3. Mechanism of PC-mediated cell cycle arrest

\begin{tabular}{lll}
\hline Checkpoints & Cell line & Ref. \\
\hline G0 / G1 & HT-29 & {$[54]$} \\
& A549 & {$[54]$} \\
& MDA-MB-231 & {$[6]$} \\
& 686 LN-M4C1 & {$[66]$} \\
G2/ M & K562 & {$[87]$} \\
& Panc-1 & {$[81]$} \\
& SKOV-3 & {$[88]$} \\
& HepG2 & {$[56]$} \\
\hline
\end{tabular}

\section{Pro-apoptotic effects}

Apoptosis, also known as programmed cell death, is a complementary mechanism with cell proliferation in cell life. When the cells undergo apoptosis, the cells have the following morphological characteristics: cell membrane bubbling, cell shrinkage and cytoplasmic coagulation. When cell apoptosis occurs, activation of endonuclease / specific protease leads to genomic cleavage, chromosome DNA fragmentation and ultimately formation of apoptotic bodies [89]. Two major apoptotic pathways have been demonstrated: one is the mitochondrial / cytochrome $C$ (endogenous) pathway, which activates Caspase- 9 and Caspase-3; the second pathway is the cell membrane surface death receptor (exogenous) pathway, in which the exogenous signal activates Caspase- 8 and Caspase-3 [90]. Caspase- 3 is activated during most of the apoptosis [91]. Caspase-3 will eventually induce apoptosis, including DNA fragmentation and cell shrinkage [92]. Therefore, tumor cell apoptosis is the key to tumor therapy. It is extremely important to study drugs that can induce tumor cell apoptosis without affecting other normal cellular functions during tumor therapy.

It is a crucial to look for new anti-cancer therapies which could promote cancer cell apoptosis. In this case, several researches reported the pro-apoptotic effect of phycocyanin on various human cancer cells and some markers were found changeable after treatment (Table 4). 
Table 4. Pro-apoptotic effect of phycocyanin on different cancer cell lines

\begin{tabular}{|c|c|c|c|}
\hline Cell line & Origin & Markers & Ref. \\
\hline MDA-MB-231 & Breast cancer & $\begin{array}{l}\text { Caspase- } 9 \text { activation } \\
\text { Production of ROS and singlet oxygen radicals } \\
\text { Cytochrome c release } \\
\text { Decrease the levels of Bcl-2, p-AKT, cyclin E and CDK2 } \\
\text { Increase the levels of p21, y-H2AX and Bax } \\
\text { Decrease the level of Bcl-2/Bax }\end{array}$ & {$[6,93]$} \\
\hline MCF-7 & Breast cancer & $\begin{array}{l}\text { Caspase- } 9 \text { activation } \\
\text { Cytochrome c release } \\
\text { Decrease the level of Bcl-2 } \\
\text { Up-regulation of Fas } \\
\text { Disruption of MMP } \\
\text { Down-regulation of NF-KB, P53 and CD44 }\end{array}$ & {$[57,62]$} \\
\hline HT-29 & Colorectal cancer & DNA fragmentation & [66] \\
\hline HepG2 & Hepatoma & $\begin{array}{l}\text { Caspase- } 3 \text { activation } \\
\text { PARP-1 cleavage } \\
\text { DNA fragmentation } \\
\text { Disruption of MMP } \\
\text { Cytochrome c release } \\
\text { Decrease the level of Bcl-2 } \\
\text { Increase the level of Bax } \\
\text { Decrease the level of Bcl-2/Bax }\end{array}$ & {$[56,63,94]$} \\
\hline K562 & Leukemia & $\begin{array}{l}\text { DNA fragmentation } \\
\text { PARP-1 cleavage } \\
\text { Cytochrome c release } \\
\text { Decrease the level of Bcl-2 } \\
\text { Decrease the level of Bcl-2/Bax }\end{array}$ & [67] \\
\hline A549 & Lung cancer & $\begin{array}{l}\text { DNA fragmentation } \\
\text { Down-regulation of NF-кB } \\
\text { Increase the levels of p38 MAPK }\end{array}$ & {$[64]$} \\
\hline A375 & Melanoma & $\begin{array}{l}\text { DNA fragmentation } \\
\text { Disruption of MMP }\end{array}$ & [62] \\
\hline 686LN-M4C1 & squamous cell carcinoma & Caspase- 8 and -3 activation & {$[66]$} \\
\hline AK-5 & Rat histiocytic tumor & $\begin{array}{l}\text { DNA fragmentation } \\
\text { Production of ROS } \\
\text { Decrease the levels of Bcl-2, COX-2 }\end{array}$ & [95] \\
\hline RAW 264.7 & mouse macrophages cell & $\begin{array}{l}\text { PARP-1 cleavage } \\
\text { Cytochrome c release } \\
\text { DNA fragmentation } \\
\text { Production of ROS } \\
\text { Decrease the levels of Bcl-2, COX-2, PEG2 }\end{array}$ & [75] \\
\hline HeLa & human cervical cancer & $\begin{array}{l}\text { Caspase-2, 3, 4, 6, 8, } 9 \text { and } 10 \text { activation } \\
\text { DNA fragmentation } \\
\text { Down-regulation of Fas, ICAM-1 and Bcl-2 } \\
\text { Cytochrome c release } \\
\text { Decrease the levels of CD59, cyclin D1 and CDK4 }\end{array}$ & {$[76,96,97]$} \\
\hline LNCaP & Prostate carcinoma & $\begin{array}{l}\text { Caspase- } 9 \text { and }-3 \text { activation } \\
\text { ROS production }\end{array}$ & [98] \\
\hline PANC-1 & pancreatic cancer & $\begin{array}{l}\text { Caspase- } 3 \text { activation } \\
\text { PARP-1 cleavage } \\
\text { Stimulation of the NF-KB pathway } \\
\text { Inhibition of the Akt/mTOR/p70S6K pathway } \\
\text { Increase the levels of p-JNK and p-p38 } \\
\text { Decrease the level of p-ERK }\end{array}$ & [81] \\
\hline HEP-2 & Laryngeal cancer & $\begin{array}{l}\text { Caspase- } 3,8 \text { and } 9 \text { activation } \\
\text { ROS production } \\
\text { Increase the levels of Bax, Fas and p53 } \\
\text { Decrease the level of Bcl-2 } \\
\text { Decrease the level of Bcl-2/Bax }\end{array}$ & [99] \\
\hline SKOV-3 & Human ovarian cancer & $\begin{array}{l}\text { Apoptosis bodies } \\
\text { Improve the intracellular content of ROS } \\
\text { Caspase- } 3,8 \text { and } 9 \text { activation } \\
\text { Increase the level of mtSSB } \\
\text { Decrease the levels of PSME3, HSP60, nucleolin, PPase and prdx-4 }\end{array}$ & [100] \\
\hline COLO 205 & Human colon carcinoma & $\begin{array}{l}\text { Chromatin condensation } \\
\text { Nuclear fragmentation } \\
\text { DNA strand break } \\
\text { Caspase- } 3 \text { and } 9 \text { activation } \\
\text { Mitochondrial membrane depolarization } \\
\text { Increase the level of Bax } \\
\text { Cytochrome c release }\end{array}$ & [101] \\
\hline
\end{tabular}


As shown in Table 4, phycocyanin is capable of activating the mitochondrial / cytochrome C (endogenous) pathway, altering the $\mathrm{Bcl}-2 / \mathrm{Bax}$ ratio (Bcl-2, anti-apoptotic protein; Bax, pro-apoptotic protein; Bcl-2/Bax ratio represents apoptosis degree) and activating caspases and inducing poly (ADP-ribose) polymerase-1 (PARP-1) cleavage [67]. In addition, phycocyanin can alter the mitochondrial membrane potential (MMP), which leads to a decrease of Bcl-2 expression [62]. Mitochondrial membrane changes stimulate the release of cytochrome c, promote the formation of reactive oxygen species (ROS) that has cytotoxic effects on cancer cells, and ultimately trigger apoptosis [75]. Under confocal microscopy, the phycocyanin is located within the mitochondria, which can explain its apoptotic effect [56]. Similarly, phycocyanin can activate the cell membrane surface death receptor (exogenous) pathway, activate the FAS protein, and promote apoptosis [57, 96].

When phycocyanin treated breast cancer MBA-MD-231 cells, phycocyanin triggered the apoptosis of MBA-MD-231 cells by forming ROS, overexpressing p21 protein and lowering Bcl-2 / Bax levels [6, 93]. Apoptosis of MCF7 cells induced by phycocyanin was related to FAS over-expression, MMP changes, down-regulation of NF-kB, P53 and Bcl-2 expression [57, 62]. Apoptosis of leukemia cell line K562 induced by phycocyanin involved down-regulation of Bcl-2 / Bax and activation of PARP-1 [67]. HepG2 cells showed that phycocyanin stimulated the apoptotic process by activating PARP-1, altering MMP and decreasing Bcl-2 / Bax levels [63]. In addition, when AK5 was treated with C-phycocyanin, ROS was activated but $\mathrm{Bcl}-2$ and COX-2 expression were inhibited [95]. C-phycocyanin-induced Hela cell apoptosis was caspase-dependent. Activation of caspase-2, -3, -4, -6, $-8,-9$ and -10 were involved in C-phycocyanin therapy [96].In colon cancer HT-29 cells and lung adenocarcinoma A549 cells, phycocyanin decreased cell viability by inducing apoptosis in a dose-dependent manner. Phycocyanin treatment increased the cell nucleus cohesion and DNA fragments, and triggered HT-29 and A549 cells to stay in the G0 / G1 phase in a dose-dependent manner [54].

Some researchers suggested that MAPK, PI3K/Akt/ mTOR and NF-KB signaling pathways were directly involved in phycocyanin-induced PANC-1 cell death [81]. Gaoyong Liao found that phycocyanin increased the levels of p-JNK and p-p38 and reduced $p$-Erk levels in a time-dependent manner. MAPK signaling played an important role in phycocyanin-induced apoptosis of cancer cells. Similarly, phycocyanin inhibited p-Akt (Ser473) and p-mTOR (Ser2448) in a time-dependent manner, while phycocyanin treatment increased the nuclear fraction of NF-kB in a time-dependent manner without affecting cytoplasmic NF-kB.

Mathangi Ravi found that phycocyanin-induced apoptosis of MDA-MB-231 cells through down-regulation ERK1/2. Phycocyanin decreased phosphorylation of ERK1/2, down-regulated of Mcl-1 expression. In general, phycocyanin-induced apoptosis of MDA-MB-231 cells can be attributed to phycocyanin inhibition of MAPK signaling pathway, at the same time, phycocyanin is non-toxic to nonmalignant cells, platelets and RBCs. The study by Mathangi Ravi also demonstrated that the phycocyanin reduces the anti-angiogenic effect by inhibiting COX-2 levels, while C-phycocyanin reduces the expression of MMP-9 and blocks the invasion process [6].

In K562 cells, the levels of phosphorylated BCR-ABL and phosphorylated PI3K were decreased after treated with phycocyanin, whereas BCR-ABL and PI3K levels did not change significantly. AKT and p-AKT were reduced after phycocyanin treatment for 1 hour. Anti-proliferative effects of C-PC are mediated by BCR-ABL signaling and inactivation of downstream pathway PI3K / AKT [80].

\section{Combined use with drugs and radiation}

Many studies have shown that two or more drug combinations can be used to treat the disease in order to improve the therapeutic effect [102]. In the course of tumor treatment, different drug combinations can effectively improve the safety and efficacy of a single drug in cancer treatment regimen. When phycocyanin combined with these chemotherapy drugs, chemotherapy drugs dose can be reduced and thus minimize side effects. Phycocyanin can potentially improve the efficacy of currently available anti-cancer drugs. It is reported that diverse drugs and radiation may combine with phycocyanin to kill human cancer cells (Table 5).

Miroslav [98] treated LNCaP (prostate cancer) with $10 \%$ conventional doses of topotecan and C-phycocyanin (C-PC), the effect was better than single topotecan or C-PC treatment. The combination of C-phycocyanin and topotecan has activated a large number of caspase- 9 and caspase-3, increased free radical oxygen (ROS) levels, induced apoptosis of tumor cells, and reduced side effects of topotecan. 
Table 5. Synergic effects of phycocyain with chemotherapy drugs or radiation

\begin{tabular}{|c|c|c|c|c|c|}
\hline Drug & $\begin{array}{l}\text { Cell lines/ } \\
\text { animal model }\end{array}$ & origin & concentration & Markers & Ref. \\
\hline $\begin{array}{l}\text { Topotecan (TPT) } \\
+ \text { Phycocyanin } \\
(\mathrm{PC})\end{array}$ & LNCaP & $\begin{array}{l}\text { Limnothrix } \\
\text { sp. 37-2-1 }\end{array}$ & $\begin{array}{l}\text { TPT }(10 \% \text { of typical } \\
\text { dose })+ \text { PC } \\
(500 \mu \mathrm{g} / \mathrm{L})\end{array}$ & $\begin{array}{l}\text { Reduce the effective dose of TPT } \\
\text { Increase level of DNA fragmentation } \\
\text { Increase level of ROS } \\
\text { Increase activities of caspase- } 9 \text { and caspase- } 3\end{array}$ & [98] \\
\hline $\begin{array}{l}\text { Piroxicam+ } \\
\text { C-phycocyanin } \\
\text { (C-PC) }\end{array}$ & $\begin{array}{l}\text { DMH-induced } \\
\text { rat colon } \\
\text { carcinogenesis }\end{array}$ & $\begin{array}{l}\text { Spirulina } \\
\text { platensis }\end{array}$ & $\begin{array}{l}\text { Piroxicam } \\
(4 \mathrm{mg} / \mathrm{kg})^{+} \\
\text {C-PC }(200 \mathrm{mg} / \mathrm{kg})\end{array}$ & $\begin{array}{l}\text { Reduce the toxicity and side effects of Piroxicam } \\
\text { Significant decrease levels of COX-2 and PGE2 } \\
\text { Significant increase the number of apoptotic cells } \\
\text { Increase level of DNA fragmentation } \\
\text { Reduce the number and size of tumors } \\
\text { Increase the tumor inhibition rate } \\
\text { Stimulate cytochrome c release } \\
\text { Significant down-regulate the Bcl-2 expression } \\
\text { Increase activities of caspase- } 9 \text {, caspase-3 and Apaf-1 } \\
\text { Augment intracellular Ca(+2) } \\
\text { Elevate calpain- } 9 \text { expression } \\
\text { Up-regulate Wnt/ } \beta \text {-catenin pathway } \\
\text { Down-regulation PPARY expression }\end{array}$ & $\begin{array}{l}{[103} \\
105]\end{array}$ \\
\hline $\begin{array}{l}\text { all-trans-retinoic } \\
\text { acid (ATRA) + } \\
\text { C-phycocyanin } \\
\text { (C-PC) }\end{array}$ & HeLa & $\begin{array}{l}\text { Spirulina } \\
\text { platensis }\end{array}$ & $\begin{array}{l}\text { ATRA } \\
(0.079 \mathrm{mM})^{+} \\
\text {C-PC }(96 \mu \mathrm{g} / \mathrm{L})\end{array}$ & $\begin{array}{l}\text { Reduce the effective dose and the toxicity of ATRA } \\
\text { Enhance the inhibit effect of HeLa cells growth } \\
\text { Inhibit the progress of the cell cycle } \\
\text { Induce more G0/G1 cell cycle arrest } \\
\text { Decrease cyclin D1 and CDK4 expressions } \\
\text { Induce cell apoptosis } \\
\text { Upregulate caspase-3 expression } \\
\text { Downregulate the Bcl-2 expression } \\
\text { Promote complement-mediated cytolysis. } \\
\text { Downregulate the CD59 expression }\end{array}$ & $\begin{array}{l}{[65,} \\
97, \\
106]\end{array}$ \\
\hline $\begin{array}{l}\text { Betaine }+ \\
\text { C-phycocyanin } \\
\text { (C-PC) }\end{array}$ & A549 & $\begin{array}{l}\text { Spirulina } \\
\text { platensis }\end{array}$ & $\begin{array}{l}\text { Betaine }(4 \%)+ \\
\text { C-PC }(20 \mu \mathrm{g} / \mathrm{L})\end{array}$ & $\begin{array}{l}\text { Enhance betaine anti-cancer effects. } \\
\text { Significant decrease A549 viability } \\
\text { Inhibit the progress of the cell cycle } \\
\text { Significant decrease NF- } \mathrm{KB} \text { activation } \\
\text { Significant increase total p38 MAPK expression } \\
\text { Significant decrease in tumour weight }\end{array}$ & {$[64]$} \\
\hline $\begin{array}{l}\text { Doxorubicin } \\
(\text { DOX)+ } \\
\text { C-phycocyanin } \\
\text { (C-PC) }\end{array}$ & $\begin{array}{l}\text { Adult rat } \\
\text { ventricular } \\
\text { cardiomyocyte } \\
\text { s }\end{array}$ & $\begin{array}{l}\text { Spirulina } \\
\text { platensis }\end{array}$ & $\begin{array}{l}\text { DOX }(1 \mu \mathrm{M})+ \\
\text { C-PC }(10 \mu \mathrm{M}) \text { or } \\
\text { Spirulina }(50 \\
\mu \mathrm{g} / \mathrm{mL})\end{array}$ & $\begin{array}{l}\text { Significant attenuate the DOX-induced ROS increase } \\
\text { Decrease the number of DOX-induced apoptotic cells } \\
\text { Prevent the DOX-induced DNA fragmentation } \\
\text { Inhibit DOX-induced Bax expression } \\
\text { Inhibit the DOX-induced caspase-3 activation } \\
\text { Inhibit the DOX-induced cytochrome c release } \\
\text { Increase in the Bcl-2 / Bax ratio }\end{array}$ & {$[107]$} \\
\hline $\begin{array}{l}\text { Doxorubicin } \\
(\text { DOX })+ \\
\text { C-phycocyanin } \\
\text { (C-PC) }\end{array}$ & HepG2 & $\begin{array}{l}\text { Spirulina } \\
\text { platensis }\end{array}$ & $\begin{array}{l}\text { DOX }(50 \mu \mathrm{M})+ \\
\text { C-PC } \\
(5,25 \text { and } 50 \mu \mathrm{M})\end{array}$ & $\begin{array}{l}\text { Reduce effective dose of doxorubicin } \\
\text { Synergistic effects on the anti-proliferation of HepG2 cells } \\
\text { Increase the accumulation of doxorubicin in HepG } 2 \text { cells }\end{array}$ & [63] \\
\hline $\begin{array}{l}\text { 625-nm laser + } \\
\text { C-phycocyanin } \\
\text { (C-PC) }\end{array}$ & $\begin{array}{l}\text { MDA-MB-231 } \\
\text { HEK-293 }\end{array}$ & $\begin{array}{l}\text { Spirulina } \\
\text { platensis }\end{array}$ & $\begin{array}{l}625-\mathrm{nm} \text { laser }(80 \\
\left.\mathrm{Mw} / \mathrm{cm}^{2}, 30 \mathrm{~min}\right)+ \\
\mathrm{C}-\mathrm{PC}(200 \mu \mathrm{g} / \mathrm{mL} \\
\text { and } 300 \mu \mathrm{g} / \mathrm{mL})\end{array}$ & $\begin{array}{l}\text { Produce enough ROS and singlet oxygen radicals } \\
\text { Disturb Cellular Morphology } \\
\text { Nuclei Cleavage } \\
\text { Cell Death } \\
\text { Disruption of MMP }\end{array}$ & [93] \\
\hline $\begin{array}{l}\text { He-Ne laser }+ \\
\text { C-phycocyanin } \\
(\text { C-PC) }\end{array}$ & HepG2 & $\begin{array}{l}\text { Microcystis } \\
\text { aeruginosa }\end{array}$ & $\begin{array}{l}\text { He-Ne laser } \\
(632.8 \mathrm{~nm}, \\
45 \mathrm{~mW} / \mathrm{cm}^{2}, 26 \\
\left.\mathrm{~J} / \mathrm{cm}^{2}\right)+\mathrm{C}-\mathrm{PC} \\
(200 \mu \mathrm{g} / \mathrm{mL})\end{array}$ & $\begin{array}{l}\text { Induce high level of ROS accumulation } \\
\text { Cause mitochondrial damage } \\
\text { Increase cytochrome c release } \\
\text { Activate caspase-3 } \\
\text { G2/M cell cycle arrest } \\
\text { Inhibit cell growth } \\
\text { Induce HepG2 cell death by apoptosis } \\
\text { Disruption of MMP } \\
\text { C-PC is localized in mitochondria }\end{array}$ & [56] \\
\hline $\begin{array}{l}\text { He-Ne laser }+ \\
\text { C-phycocyanin } \\
(\text { C-PC) }\end{array}$ & MCF-7 & $\begin{array}{l}\text { Spirulina } \\
\text { platensis }\end{array}$ & $\begin{array}{l}\text { He-Ne laser } \\
(632.8 \mathrm{~nm}, \\
24 \mathrm{~mW} / \mathrm{cm}^{2} \\
\left.76.43 \mathrm{~J} / \mathrm{cm}^{2},\right)^{+} \\
\text {C-PC }(320 \mathrm{mg} / \mathrm{ml})\end{array}$ & $\begin{array}{l}\text { Strikingly inhibit tumor formation. } \\
\text { Especially enhance immune-enhancing activity } \\
\text { Promote the Fas expression of tumor tissue } \\
\text { Restrain the CD } 44, \text { NF-KB and P53 expressions } \\
\text { Enhance inhibitory effect against the proliferation of MCF-7 cells in vitro } \\
\text { Induce MCF-7 cells death by apoptosis. } \\
\text { Increase caspase- } 9 \text { activities and cytochrome c release } \\
\text { Down-regulate the Bcl-2 protein }\end{array}$ & [57] \\
\hline
\end{tabular}

Saini [103] also demonstrated that when the combination of piroxicam (the traditional non-steroidal anti-inflammatory drug) and phycocyanin treated $\mathrm{DMH}$-induced rat colon carcinogenesis, the effect was more than $70 \%$ higher than single-use drugs. DNA fragmentation, cyclooxygenase 2 (COX-2) expression and prostaglandin E2 (PGE-2) levels were significantly 
reduced. In addition, the number and size of tumors were also reduced.

Bing Li [97] found that ATRA and C-phycocyanin combination treatment of HeLa cells could significantly reduce the dose and side effects of ATRA. The combination therapy can significantly down-regulate anti-apoptotic protein Bcl-2, up-regulate the expression of pro-apoptotic Caspase-3 protein, inhibit cell cycle related CDK-4 and Cyclin D1 protein expression, inhibit complement regulatory protein CD59 expression and induce the HeLa cell apoptosis.

When lung cancer A549 cells were treated with the combination therapy of betaine and C-phycocyanin (C-PC), A549 cell viability decreased up to $60 \%$, and the effect was better than the conventional dose of betaine or C-phycocyanin. Betaine and C-phycocyanin (C-PC) combination therapy reduced NF-kB expression, increased the amount of pro-apoptotic protein p38 MAPK and induced cell G2/M cell cycle arrest. In additon, C-PC and betaine combination therapy might effectively inhibit tumor growth in rats [64].

The formation of reactive oxygen species (ROS) and DNA fragmentation induced by Doxorubicin (DOX) was significantly attenuated when adult rats were pretreated with C-phycocyanin. Cell apoptosis rate induced by doxorubicin was significantly reduced. Thus, C-phycocyanin reduced doxorubicininduced oxidative stress and cardiomyocyte apoptosis [107].

Phycocyanin could be combined with $\mathrm{He}-\mathrm{Ne}$ laser for the treatment of tumors [56, 57]. When HepG2 cells were pretreated with phycocyanin and laser irradiation (He-Ne), phycocyanin, as a photosensitizer, induced mitochondrial membrane potential loss, increased ROS, released cytochrome c, activated caspase-3, led to G2/M cell cycle arrest, then promoted HepG2 cells activate endogenous pathways to initiate apoptosis [56]. While phycocyanin could not play a role in normal human hepatocyte line HL7702.

Bing $\mathrm{Li}$ found that C-PC-mediated photodynamic therapy (PDT) could promote MCF-7 cell apoptosis in mouse tumor models. When C-PC combined with He-Ne laser irradiation, C-PC treatment effect was further improved, the immune function of mouse tumor model increased, the proliferation of immune cells increased, meanwhile, the expression of Fas protein increased, while tumor weight and anti-apoptosis protein (NF-kB) and CD44 mRNA expression decreased. In addition, caspase-9 expression was activated, cytochrome $\mathrm{c}$ released, Bcl-2 expression was down-regulated, apoptotic signal transduction was activated, eventually C-PC led to
MCF-7 cell apoptosis [57].

C-phycocyanin as a photosensitizer was used for low-level laser therapy under laser irradiation. In the $625 \mathrm{~nm}$ laser irradiation, c-phycocyanin induced ROS to produce cytotoxic reaction, induced the apoptosis of MDA-MB-231 [93].

\section{Targeted therapy and nanoparticle therapy}

The novel nano-drug may lead to the development of a new treatment strategy for cancer cells. Nano-drugs have opened up a new hot spot in the field of medicine research, which have the potential to overcome the shortcomings of conventional drugs with serious side effects in vivo [108]. The combination of medicine and nanotechnology provides a promising way to solve these problems, and many reports have proven the anticancer efficacy of nano-drugs for various cancer types in vivo and in vitro. The specifically expressed and overexpressed proteins in cancer cells are considered to be a useful molecular marker, which is constructed as tumor-targeted nano-drugs that specifically target nano-drugs to tumors. Thus, tumor-targeted nano-drugs are selective killing of cancer cells, while tumor-targeted nano-drugs have the least effect on normal cells. At present, tumor targeting Nano-drugs have become a hot topic.

Xiaoxia Liao successfully constructed a novel biomedical material, MWNT-CS-PC, with a combination of chitosan (CS), multiwalled carbon nanotubes (MWNTs) and phycocyanin (PC). Water-soluble chitosan served as a skeleton, which can bridge between two photo-responsive materials (phycocyanin and multiwalled carbon nanotubes). MWNT-CS-PC utilized different advantages of each component, such as the easy modification, solubility and low toxicity of chitosan, the photothermal effect of multiwalled carbon nanotubes in the near-infrared light region, and the low toxicity and photodynamic response of phycocyanin in the visible light region. It is reported that the average length of the MWNT-CS-PC was $233 \mathrm{~nm}$ and the zeta potential of the MWNT-CS-PC was $62.2 \mathrm{mV}$. It is noted that MWNT-CS-PC could inhibit the proliferation of L-o2, MCF-7 and HepG2 cells, and enhance the photoinduced cytotoxicity of MCF-7 and HepG2 cells with irradiation of both near-infrared light $(808 \mathrm{~nm})$ and visible light $(532 \mathrm{~nm})$. Phycocyanin could improve the phototoxicity of MWNT-CS-PC and also reduce the cytotoxicity of the carbon nanotube complex on normal cells L-o2. However, it is essential that MWNT-CS-PC conjugate tumor-associated antigen to enhance the targeting ability, so MWNT-CS-PC will possess high potential for photodynamic therapy of cancer [109]. 
Peng Yang successfully constructed a novel nano-drug, C-PC/CMC-CD59sp nanoparticles, with a combination of C-phycocyanin (C-PC), Carboxymethyl chitosan (CMC) and CD59-specific ligand peptide (CD59sp). Carboxymethyl chitosan served as a vehicle, which can bridge between C-phycocyanin and CD59sp. It was reported that the C-PC/CMC-CD59sp nanoparticles were spherical, the mean length of C-PC/CMC-CD59sp nanoparticles was $200 \mathrm{~nm}$, and the C-phycocyanin loading of C-PC/CMC-CD59sp nanoparticles was about $20 \%$. The C-PC/CMC-CD59sp nanoparticles loaded with Water-soluble C-PC improved stability of C-PC and had sustained anticancer activity. Guided by the CD59-specific ligand peptide, the C-PC/CMCCD59sp nanoparticles efficiently targeted the surface of HeLa cells and could be more effective in inhibiting HeLa cell proliferation. The C-PC/CMC-CD59sp nanoparticles induced HeLa cells apoptosis by up-regulation of cleaved caspase- 3 and cleaved poly ADP-ribose polymerase proteins, and downregulation of $\mathrm{Bcl}-2$ proteins [110].

Dong-Hua Wan used C-phycocyanin (C-PC) as a vehicle of zinc phthalocyanine $(\mathrm{ZnPc})$ to fabricate a $\mathrm{ZnPc-CPC}$ conjugate. It was reported that the zeta potential of the $\mathrm{ZnPc}-\mathrm{CPC}$ conjugate is $-44.2 \mathrm{mV}$. The combination of $\mathrm{ZnPc}$ and $\mathrm{C}-\mathrm{PC}$ could effectively enhance the solubility of $\mathrm{ZnPc}$ in aqueous media. C-phycocyanin have the specific affinity to the scavenger receptor-A (SR-A), similarly, zinc phthalocyanine could selectively bind the scavenger receptor-A (SR-A), which is highly expressed on tumor-associated macrophages (TAM). Thus, the non-covalent $\mathrm{ZnPc}-\mathrm{CPC}$ conjugate could also target the tumour-associated macrophages. The tumour-associated macrophages have been shown to play a crucial role in the development and progression of cancer. So tumour-associated macrophages have been proposed to be a "target for cancer therapy". The ZnPc-CPC conjugate selectively accumulated in tumor sites probably through the TAM-mediated mechanism. And the ZnPc-CPC conjugate exhibited an efficient in vitro photodynamic activity. Thus, C-phycocyanin can act as a new class of TAM-targeted photosensitiser as well as a desirable vehicle for photosensitisers. This provides a novel strategy to enhance the efficacy for cancer therapy [70].

\section{Effect on tumor progression and metastasis}

Another basic feature of phycocyanin is the impact of tumor progression and metastasis potential, C-phycocyanin from Spirulina was used to chemically prevent DMH-induced colon cancer in rats. After C-phycocyanin treated DMH-induced rats, the number and size of tumors / lesions were reduced. At the same time, phycocyanin could bind to VEGFR1 alone. In addition, C-phycocyanin down-regulated levels of VEGF-A, MMP-2 and MMP-9, which are required for tumor metastasis and invasion to surrounding tissues. C-phycocyanin simultaneously down-regulated HIF-1 (associated with increased oxygen demand and angiogenesis) and MCP-1 expression (positively correlated with metastatic and poor prognosis in the tumor microenvironment), while C-phycocyanin promoted MIP-1 expression which plays a role in reducing angiogenesis [79]. Similarly, C-phycocyanin from Spirulina increased calpain-9 (calpain-9 could increase intracellular $\mathrm{Ca}^{2+}$ concentration, which contributes to drug-mediated apoptosis) and PPARY (related to tumor progression), while C-phycocyanin inhibited colon cancer Wnt/ $\beta$ -catenin signal and played its anti-tumor effect, then down-regulates PPARa and PPARס expression. So C-phycocyanin has the effects of promoting apoptosis and reducing carcinogenicity [111].

C-phycocyanin inhibited the progression of cancer by inhibiting pro-inflammatory cytokines and Jak3 / Stat3 signaling [77]. C-phycocyanin from cyanobacteria down-regulated the expression of pro-inflammatory cytokines (IL-1 $\beta$, IL-2, interferon- $\gamma$ and tumor necrosis factor- $\alpha$ ), transcription factors (Janus kinase 3 (Jak3) and signal transducers and activators of transcription 3(stat3)) and enhanced the expression of anti-inflammatory cytokines IL-4 in DMH-induced colon cancer.

Phycocyanin has a therapeutic effect on the invasion of tumor cells. After treatment with phycocyanin, actin filaments were destroyed in MDA-MB-231 cell, the cell polymerization capacity increased while the migration potential decreased [6]. Phycocyanin is an inhibitor of COX-2 which biological function is to convert arachidonic acid to prostaglandins and plays a key role in tumor progression and chemical resistance $[112,113]$. PGE-2 is a tightly regulated product of COX-2, which is characterized by promoting angiogenesis [114]. It has been shown that COX-2 inhibitors up-regulated E-cadherin expression in colon cancer cell lines [115]. The expression of COX-2 was positively correlated with tumor invasion, metastasis and poor prognosis in non-small cell lung cancer (NSCLC). Overexpression of COX-2 resulted in a decrease in E-cadherin expression and a decrease in cell aggregation capacity in NSCLC cells. Exogenous prostaglandin E2 (PGE2) significantly reduced E-cadherin in the treatment of NSCLC cells. ZEB1 and Snail (transcriptional inhibitors of E-cadherin) were up-regulated in COX-2 overexpressed cells or PGE2-treated NSCLC cells, and PGE2 enhanced the 
binding of ZEB1 and Snail to E-cadherin at the chromatin level. Therefore, PGE2 regulated the transcriptional inhibitory factor of E-cadherin to regulate the expression of COX-2-dependent E-cadherin in NSCLC [116].

C-phycocyanin inhibited EMT by reducing the expression of vimentin, type 1 collagen and fibronectin, and increasing the expression of E-cadherinin in TGF- $\beta 1$-treated cells. Thus, C-phycocyanin inhibited TGF- $\beta 1$-induced EMT, so C-phycocyanin might be a potential anti-fibrosis drug [74].

\section{Induction of autophagy}

It was reported that autophagy is a double-edged sword, in addition to contributing to cell damage, as well as well-known to promote survival [117, 118]. Autophagy also plays a role in cancer cells, such as protecting cancer cells from death [119]. But specific cancer cells can be killed by autophagy, in which case autophagy acts as a programmed cell death type II [120, 121], sometimes, autophagy plays a role in killing tumor cells when autophagy interacted with other cell death mechanisms [122]. In particular, autophagy and apoptosis are usually induced by the same stimulus and share similar effectors and regulators [123, 124]. These studies have shown that it is highly probable to develop anti-cancer treatment strategies by synergistically regulating autophagy and apoptosis. In view of these factors, many studies were actively looking for drugs that not only induce apoptosis but also induce autophagy. In this regard, some studies had shown that phycocyanin acted as a potential inducer for autophagy.

Gaoyong Liao [81] found that phycocyanin was able to induce autophagy in PANC-1 cells. When phycocyanin treated PANC-1 cells, the expression of Beclin 1 increased with the increase of phycocyanin dose and treatment time. As a mammalian homologous protein of yeast Atg6, Beclin 1 plays a crucial role in the process of autophagy induction and the formation of characteristic autophagosomes. Gaoyong Liao had shown that phycocyanin inhibited Akt/mTOR/p70S6K signaling pathways, which may contribute to phycocyanin-induced autophagy. Several studies have also shown that $\mathrm{Akt} / \mathrm{mTOR} / \mathrm{p} 70 \mathrm{S6K}$ pathway plays an important role in the development of autophagy in various cancer cells, including liver cancer [125], gastric cancer [126], pancreatic cancer [127] and malignant glioma [128]. Protein kinase Akt could inhibit tuberous sclerosis complex 2 (TSC2) by direct phosphorylation, to further up-regulate mTOR [129], which has been considered a key regulator of autophagy [130].
Otherwise, cancer cells could be induced to trigger autophagy by inhibition of mTOR pathway [131, 132]. At the same time, phycocyanin activated JNK and p38 pathway and inhibited ERK signaling pathway. The study showed that MAPK signal pathway played an important role in phycocyanin-induced apoptosis of cancer cells. Autophagy and apoptosis usually coexisted and remained in balance with each other [133].

Although there is a significant difference between apoptosis and autophagy, sometimes the same regulators can regulate both apoptosis and autophagy [134]. One such modulator is the NF-kB signaling pathway. When NF- $\mathrm{kB}$ signaling pathway is activated, it is well known that apoptosis would be inhibited [135, 136], autophagy would be regulated in a positive or negative regulatory manner [137-140].

Phycocyanin can induce NF-kB nuclear translocation, since NF- $\mathrm{kB}$ is one of the transcription factors of Beclin 1 which is a key promoter of autophagy in cells [141], so the expression of Beclin 1 was highly correlated with the amount of NF-kB transferred into the nucleus. In other words, phycocyanin-activated NF-kB nuclear translocation increased autophagy by increasing the transcription of the Beclin 1. Thus, phycocyanin-mediated complex interactions between autophagy and apoptosis may be due to NF-KB activation. In conclusion, phycocyanin induced apoptosis and autophagy by complex regulation of MAPK, Akt/mTOR and NF-kB signaling pathways.

In conclusion, the present study suggested that the NF-kB, MAPK, PI3K-Akt-mTOR pathways were involved in both phycocyanin-induced tumor cells apoptosis and autophagy (Figure 1). These findings therefore strongly suggested that the anticancer activities of phycocyanin.

\section{Concluding remarks}

It is shown that phycocyanin has a clear potential as a drug in a wide range of studies. More and more literatures supported that phycocyanin might be a promising anticancer drug or supplementary drug of anticancer drug. On one hand, the constructions of targeted-tumor nano-drug or nanoparticles have become a hot spot for phycocyanin treatment of tumors. Targeted therapy and nanoparticle therapy have now become a hot topic in cancer treatment. Targeted therapy and nanoparticle therapy could increase anticancer effects toward cancer cells. In future, with the discovery of more and more tumor-specific antigens and nanomaterials, the construction of targeted nanoparticles is becoming more and more mature, the target to tumors is getting better, and the side effects of normal tissue cells are 
getting smaller. On the other hand, combination with other anticancer drugs and radiation for cancer therapy has become another research hotspot. Traditional anti-cancer drugs are often accompanied by serious side effects and short effective half-lives in vivo. When combined with other anticancer drugs and radiation, phycocyanin could reduce the effective dose of anticancer drugs, minimize side effects and improve the therapeutic effect. In addition, phycocyanin can effectively improve the safety and efficacy of a single anticancer drug in cancer treatment.

However, phycocyanin is currently not used as an anticancer drug for clinical use. Despite the phycocyanin target and mechanism were studied several times, it still has to investigate the molecular mechanism of phycocyanin on the death of cancer cells. Further clarifying the effect of phycocyanin on cancer and normal cells will help to develop effective strategies and instruct the clinical application.

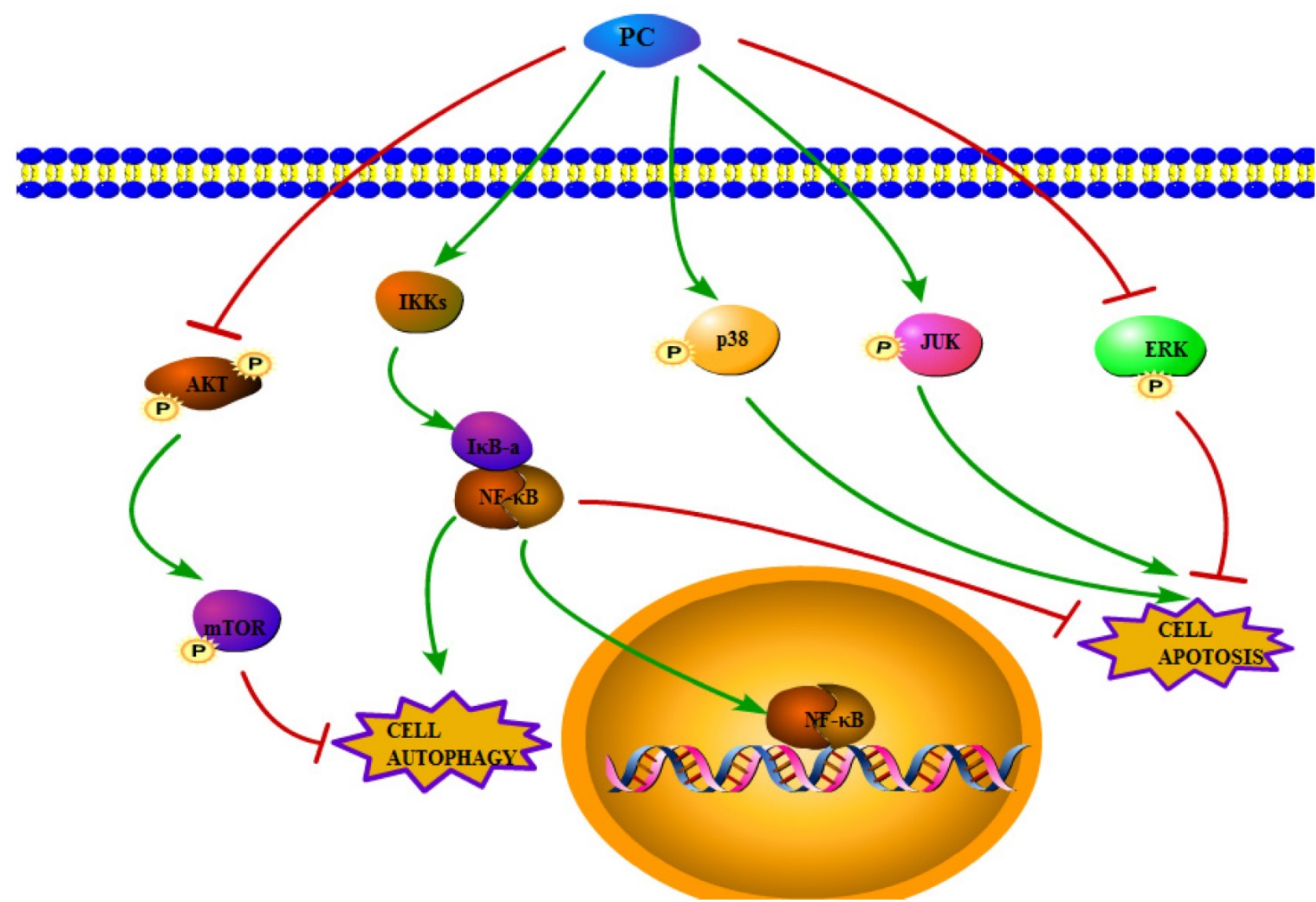

Figure 1. Schematic form of the proposed pathway mechanisms for phycocyanin-induced apoptosis and autophagy in tumor cells.

\section{Abbreviations}

PC: Phycocyanin

C-PC: C-Phycocyanin

PBP: Phycobiliprotein

PE: Phycoerythrin

AP: Allophycocyanin

PCB: Phycocyanobilin

PEB: Phycoerythrobilin

PUB: Phycourobilin

PVB: Phycoviolobilin

Jak3: Janus kinase 3

STAT3: Signal transducers and activators of transcription 3
PGE2: Prostaglandin E2

MAPK: Mitogen-activated protein kinase

PARP-1: Poly (ADP-ribose) polymerase-1

EMT: Epithelial-Mesenchymal Transition

MMP: Mitochondrial membrane potential

ROS: Reactive oxygen species

TPT: Topotecan; ATRA: All-trans-retinoic acid

DOX: Doxorubicin

RCSB PDB: the Protein Database of the United States Research Collaboratory for Structural Bioinformatics

\section{Acknowledgements}

This work was funded by the National Natural 
Science Foundation of China (81471546, 81001346, 81273206).

\section{Authors' contributions}

All authors have contributed to data preparation, drafting and revising the manuscripts. All authors have read and approved the final manuscript.

\section{Competing Interests}

The authors have declared that no competing interest exists.

\section{References}

1. Marazzi G, Cacciotti L, Pelliccia F, Iaia L, Volterrani M, Caminiti G, et al. Long-term effects of nutraceuticals (berberine, red yeast rice, policosanol) in elderly hypercholesterolemic patients. Advances in therapy. 2011; 28: 1105-13.

2. Hfaiedh M, Brahmi D, Zourgui L. Protective role of cactus cladodes extract on sodium dichromate-induced testicular injury and oxidative stress in rats. Biological trace element research. 2014; 159: 304-11.

3. Lobo V, Patil A, Phatak A, Chandra N. Free radicals, antioxidants and functional foods: Impact on human health. Pharmacognosy reviews. 2010; 4: $118-26$

4. Jung IL. Soluble extract from Moringa oleifera leaves with a new anticancer activity. PloS one. 2014; 9: e95492.

5. Bechelli J, Coppage M, Rosell K, Liesveld J. Cytotoxicity of algae extracts on normal and malignant cells. Leukemia research and treatment. 2011; 2011: 373519

6. Ravi M, Tentu S, Baskar G, Rohan Prasad S, Raghavan S, Jayaprakash P, et al. Molecular mechanism of anti-cancer activity of phycocyanin in triple-negative breast cancer cells. BMC cancer. 2015; 15: 768.

7. de Jesus Raposo MF, de Morais RM, de Morais AM. Health applications of bioactive compounds from marine microalgae. Life sciences. 2013; 93: 479-86.

8. Benedetti S, Rinalducci S, Benvenuti F, Francogli S, Pagliarani S, Giorgi L, et al. Purification and characterization of phycocyanin from the blue-green alga Aphanizomenon flos-aquae. Journal of chromatography B, Analytical technologies in the biomedical and life sciences. 2006; 833: 12-8.

9. Madhyastha HK, Radha KS, Sugiki M, Omura S, Maruyama M. Purification of c-phycocyanin from Spirulina fusiformis and its effect on the induction of urokinase-type plasminogen activator from calf pulmonary endothelial cells. Phytomedicine: international journal of phytotherapy and phytopharmacology. 2006; 13: 564-9.

10. Madamwar D, Patel DK, Desai SN, Upadhyay KK, Devkar RV. Apoptotic potential of C-phycoerythrin from Phormidium sp. A27DM and Halomicronema sp. A32DM on human lung carcinoma cells. EXCLI journal. 2015; 14: 527-39.

11. Rastogi RP, Sonani RR, Madamwar D. Effects of PAR and UV Radiation on the Structural and Functional Integrity of Phycocyanin, Phycoerythrin and Allophycocyanin Isolated from the Marine Cyanobacterium Lyngbya sp. A09DM. Photochemistry and photobiology. 2015; 91: 837-44.

12. Chen Z, Zhan J, Chen Y, Yang M, He C, Ge F, et al. Effects of Phosphorylation of beta Subunits of Phycocyanins on State Transition in the Model Cyanobacterium Synechocystis sp. PCC 6803. Plant \& cell physiology. 2015; 56: 1997-2013.

13. Shen G, Schluchter WM, Bryant DA. Biogenesis of phycobiliproteins: I. cpcS-I and $\mathrm{cpcU}$ mutants of the cyanobacterium Synechococcus sp. PCC 7002 define a heterodimeric phyococyanobilin lyase specific for beta-phycocyanin and allophycocyanin subunits. The Journal of biological chemistry. 2008; 283: 7503-12.

14. Stadnichuk IN, Krasil'nikov PM, Zlenko DV. [Cyanobacterial Phycobilisomes and Phycobiliproteins]. Mikrobiologiia. 2015; 84: 131-43.

15. MacColl R. Cyanobacterial phycobilisomes. Journal of structural biology. 1998; 124: 311-34.

16. Grossman AR, Schaefer MR, Chiang GG, Collier JL. The phycobilisome, a light-harvesting complex responsive to environmental conditions. Microbiological reviews. 1993; 57: 725-49.

17. Leganes F, Martinez-Granero F, Munoz-Martin MA, Marco E, Jorge A, Carvajal L, et al. Characterization and responses to environmental cues of a photosynthetic antenna-deficient mutant of the filamentous cyanobacterium Anabaena sp. PCC 7120. Journal of plant physiology. 2014; 171: 915-26.

18. Kirst $\mathrm{H}$, Formighieri $\mathrm{C}$, Melis A. Maximizing photosynthetic efficiency and culture productivity in cyanobacteria upon minimizing the phycobilisome light-harvesting antenna size. Biochimica et biophysica acta. 2014; 1837: 1653-64.

19. Watanabe M, Semchonok DA, Webber-Birungi MT, Ehira S, Kondo K, Narikawa R, et al. Attachment of phycobilisomes in an antenna-photosystem I supercomplex of cyanobacteria. Proceedings of the National Academy of Sciences of the United States of America. 2014; 111: 2512-7.

20. Adir N, Lerner N. The crystal structure of a novel unmethylated form of C-phycocyanin, a possible connector between cores and rods in pycobilisomes. The Journal of biological chemistry. 2003; 278: 25926-32.

21. Storf M, Parbel A, Meyer M, Strohmann B, Scheer H, Deng MG, et al. Chromophore attachment to biliproteins: specificity of $\mathrm{PecE} / \mathrm{PecF}$, a lyase-isomerase for the photoactive 3(1)-cys-alpha 84-phycoviolobilin chromophore of phycoerythrocyanin. Biochemistry. 2001; 40: 12444-56.

22. Glauser M, Stirewalt VL, Bryant DA, Sidler W, Zuber H. Structure of the genes encoding the rod-core linker polypeptides of Mastigocladus laminosus phycobilisomes and functional aspects of the phycobiliprotein/linker-polypeptide interactions. European journal of biochemistry. 1992; 205: 927-37.

23. Bennett A, Bogorad L. Properties of subunits and aggregates of blue-green algal biliproteins. Biochemistry. 1971; 10: 3625-34.

24. Glazer AN, Cohen-Bazire G. Subunit structure of the phycobiliproteins of blue-green algae. Proceedings of the National Academy of Sciences of the United States of America. 1971; 68: 1398-401.

25. O'Carra P, Killilea SD. Subunit structures of C-phycocyanin and C-phycoerythrin. Biochemical and biophysical research communications. 1971; 45: 1192-7.

26. Su HN, Wang QM, Li CY, Li K, Luo W, Chen B, et al. Structural insights into the cold adaptation of the photosynthetic pigment-protein C-phycocyanin from an Arctic cyanobacterium. Biochimica et biophysica acta. 2017; 1858: 325-35.

27. Fromme R, Ishchenko A, Metz M, Chowdhury SR, Basu S, Boutet S, et al. Serial femtosecond crystallography of soluble proteins in lipidic cubic phase. IUCrJ. 2015; 2: 545-51.

28. Conrad CE, Basu S, James D, Wang D, Schaffer A, Roy-Chowdhury S, et al. A novel inert crystal delivery medium for serial femtosecond crystallography. IUCrJ. 2015; 2: 421-30.

29. Singh NK, Hasan SS, Kumar J, Raj I, Pathan AA, Parmar A, et al. Crystal structure and interaction of phycocyanin with beta-secretase: A putative therapy for Alzheimer's disease. CNS \& neurological disorders drug targets. 2014; 13: 691-8.

30. David L, Prado M, Arteni AA, Elmlund DA, Blankenship RE, Adir N. Structural studies show energy transfer within stabilized phycobilisomes independent of the mode of rod-core assembly. Biochimica et biophysica acta. 2014; 1837: 385-95.

31. Marx A, Adir N. Allophycocyanin and phycocyanin crystal structures reveal facets of phycobilisome assembly. Biochimica et biophysica acta. 2013; 1827: 311-8.

32. David L, Marx A, Adir N. High-resolution crystal structures of trimeric and rod phycocyanin. Journal of molecular biology. 2011; 405: 201-13.

33. Contreras-Martel C, Matamala A, Bruna C, Poo-Caamano G, Almonacid D, Figueroa $\mathrm{M}$, et al. The structure at $2 \mathrm{~A}$ resolution of Phycocyanin from Gracilaria chilensis and the energy transfer network in a PC-PC complex. Biophysical chemistry. 2007; 125: 388-96.

34. Nield J, Rizkallah PJ, Barber J, Chayen NE. The 1.45 A three-dimensional structure of C-phycocyanin from the thermophilic cyanobacterium Synechococcus elongatus. Journal of structural biology. 2003; 141: 149-55.

35. Padyana AK, Bhat VB, Madyastha KM, Rajashankar KR, Ramakumar S. Crystal structure of a light-harvesting protein C-phycocyanin from Spirulina platensis. Biochemical and biophysical research communications. 2001; 282: 893-8.

36. Adir N, Vainer R, Lerner N. Refined structure of c-phycocyanin from the cyanobacterium Synechococcus vulcanus at $1.6 \mathrm{~A}$ : insights into the role of solvent molecules in thermal stability and co-factor structure. Biochimica et biophysica acta. 2002; 1556: 168-74.

37. Jiang T, Zhang JP, Chang WR, Liang DC. Crystal structure of R-phycocyanin and possible energy transfer pathways in the phycobilisome. Biophysical journal. 2001; 81: 1171-9.

38. Adir N, Dobrovetsky Y, Lerner N. Structure of c-phycocyanin from the thermophilic cyanobacterium Synechococcus vulcanus at $2.5 \mathrm{~A}$ : structural implications for thermal stability in phycobilisome assembly. Journal of molecular biology. 2001; 313: 71-81.

39. Stec B, Troxler RF, Teeter MM. Crystal structure of C-phycocyanin from Cyanidium caldarium provides a new perspective on phycobilisome assembly. Biophysical journal. 1999; 76: 2912-21.

40. Duerring M, Schmidt GB, Huber R. Isolation, crystallization, crystal structure analysis and refinement of constitutive $\mathrm{C}$-phycocyanin from the chromatically adapting cyanobacterium Fremyella diplosiphon at 1.66 A resolution. Journal of molecular biology. 1991; 217: 577-92.

41. Wang XQ, Li LN, Chang WR, Zhang JP, Gui LL, Guo BJ, et al. Structure of C-phycocyanin from Spirulina platensis at 2.2 A resolution: a novel monoclinic crystal form for phycobiliproteins in phycobilisomes. Acta crystallographica Section D, Biological crystallography. 2001; 57: 784-92.

42. Silveira ST, Quines LK, Burkert CA, Kalil SJ. Separation of phycocyanin from Spirulina platensis using ion exchange chromatography. Bioprocess and biosystems engineering. 2008; 31: 477-82.

43. Wang $\mathrm{L}, \mathrm{Qu} \mathrm{Y}, \mathrm{Fu} \mathrm{X}$, Zhao M, Wang S, Sun L. Isolation, purification and properties of an R-phycocyanin from the phycobilisomes of a marine red macroalga Polysiphonia urceolata. PloS one. 2014; 9: e101724. 
44. Chaiklahan R, Chirasuwan N, Loha V, Tia S, Bunnag B. Separation and purification of phycocyanin from Spirulina sp. using a membrane process. Bioresource technology. 2011; 102: 7159-64.

45. Oliveira EG, Rosa GS, Moraes MA, Pinto LA. Characterization of thin layer drying of Spirulina platensis utilizing perpendicular air flow. Bioresource technology. 2009; 100: 1297-303.

46. Niu JF, Wang GC, Lin XZ, Zhou BC. Large-scale recovery of C-phycocyanin from Spirulina platensis using expanded bed adsorption chromatography. Journal of chromatography B, Analytical technologies in the biomedical and life sciences. 2007; 850: 267-76.

47. Patil G, Chethana S, Madhusudhan MC, Raghavarao KS. Fractionation and purification of the phycobiliproteins from Spirulina platensis. Bioresource technology. 2008; 99: 7393-6.

48. Patel A, Mishra S, Pawar R, Ghosh PK. Purification and characterization of C-Phycocyanin from cyanobacterial species of marine and freshwater habitat. Protein expression and purification. 2005; 40: 248-55.

49. Minkova KM, Tchernov AA, Tchorbadjieva MI, Fournadjieva ST, Antova RE, Busheva M. Purification of C-phycocyanin from Spirulina (Arthrospira) fusiformis. Journal of biotechnology. 2003; 102: 55-9.

50. Patel A, Mishra S, Ghosh PK. Antioxidant potential of C-phycocyanin isolated from cyanobacterial species Lyngbya, Phormidium and Spirulina spp. Indian journal of biochemistry \& biophysics. 2006; 43: 25-31.

51. Patil G, Chethana S, Sridevi AS, Raghavarao KS. Method to obtain C-phycocyanin of high purity. Journal of chromatography A. 2006; 1127: 76-81.

52. Kuddus M, Singh P, Thomas G, Al-Hazimi A. Recent developments in production and biotechnological applications of C-phycocyanin. BioMed research international. 2013; 2013: 742859.

53. Pleonsil P, Soogarun S, Suwanwong Y. Anti-oxidant activity of holo- and apo-c-phycocyanin and their protective effects on human erythrocytes. International journal of biological macromolecules. 2013; 60: 393-8.

54. Thangam R, Suresh V, Asenath Princy W, Rajkumar M, Senthilkumar N, Gunasekaran P, et al. C-Phycocyanin from Oscillatoria tenuis exhibited an antioxidant and in vitro antiproliferative activity through induction of apoptosis and G0/G1 cell cycle arrest. Food chemistry. 2013; 140: 262-72.

55. Zhu C, Ling Q, Cai Z, Wang $Y$, Zhang $Y$, Hoffmann PR, et al. Selenium-Containing Phycocyanin from Se-Enriched Spirulina platensis Reduces Inflammation in Dextran Sulfate Sodium-Induced Colitis by Inhibiting NF-kappaB Activation. Journal of agricultural and food chemistry. 2016; 64: 5060-70.

56. Wang CY, Wang X, Wang Y, Zhou T, Bai Y, Li YC, et al. Photosensitization of phycocyanin extracted from Microcystis in human hepatocellular carcinoma cells: implication of mitochondria-dependent apoptosis. Journal of photochemistry and photobiology B, Biology. 2012; 117: 70-9.

57. Li B, Chu X, Gao M, Li W. Apoptotic mechanism of MCF-7 breast cells in vivo and in vitro induced by photodynamic therapy with C-phycocyanin. Acta biochimica et biophysica Sinica. 2010; 42: 80-9.

58. Romay C, Armesto J, Remirez D, Gonzalez R, Ledon N, Garcia I. Antioxidant and anti-inflammatory properties of C-phycocyanin from blue-green algae. Inflammation research: official journal of the European Histamine Research Society [et al]. 1998; 47: 36-41.

59. Bhat VB, Madyastha KM. C-phycocyanin: a potent peroxyl radical scavenger in vivo and in vitro. Biochemical and biophysical research communications. 2000; 275: 20-5.

60. Rimbau V, Camins A, Romay C, Gonzalez R, Pallas M. Protective effects of C-phycocyanin against kainic acid-induced neuronal damage in rat hippocampus. Neuroscience letters. 1999; 276: 75-8.

61. Rimbau V, Camins A, Pubill D, Sureda FX, Romay C, Gonzalez R, et al. C-phycocyanin protects cerebellar granule cells from low potassium/serum deprivation-induced apoptosis. Naunyn-Schmiedeberg's archives of pharmacology. 2001; 364: 96-104.

62. Chen T, Wong YS. In vitro antioxidant and antiproliferative activities of selenium-containing phycocyanin from selenium-enriched Spirulina platensis. Journal of agricultural and food chemistry. 2008; 56: 4352-8.

63. Roy KR, Arunasree KM, Reddy NP, Dheeraj B, Reddy GV, Reddanna P. Alteration of mitochondrial membrane potential by Spirulina platensis C-phycocyanin induces apoptosis in the doxorubicinresistant human hepatocellular-carcinoma cell line HepG2. Biotechnology and applied biochemistry. 2007; 47: 159-67.

64. Bingula R, Dupuis C. Study of the Effects of Betaine and/or C-Phycocyanin on the Growth of Lung Cancer A549 Cells In Vitro and In Vivo. 2016; 2016: 8162952.

65. Li B, Gao MH, Chu XM, Teng L, Lv CY, Yang $\mathrm{P}$, et al. The synergistic antitumor effects of all-trans retinoic acid and C-phycocyanin on the lung cancer A549 cells in vitro and in vivo. European journal of pharmacology. 2015; 749: 107-14.

66. Wang H, Liu Y, Gao X, Carter CL, Liu ZR. The recombinant beta subunit of C-phycocyanin inhibits cell proliferation and induces apoptosis. Cancer letters. 2007; 247: 150-8

67. Subhashini J, Mahipal SV, Reddy MC, Mallikarjuna Reddy M, Rachamallu A, Reddanna P. Molecular mechanisms in C-Phycocyanin induced apoptosis in human chronic myeloid leukemia cell line-K562. Biochemical pharmacology. 2004; 68: 453-62.

68. Gardeva E, Toshkova R, Yossifova L, Minkova K, Ivanova N, Gigova L, et al. Antitumor activity of C-phycocyanin from Arthronema africanum (Cyanophyceae). Brazilian Archives of Biology \& Technology. 2014; 57: 675-84.
69. Morcos NC, Berns M, Henry WL. Phycocyanin: laser activation, cytotoxic effects, and uptake in human atherosclerotic plaque. Lasers in surgery and medicine. 1988; 8: 10-7.

70. Wan DH, Zheng BY, Ke MR, Duan JY, Zheng YQ, Yeh CK, et al C-Phycocyanin as a tumour-associated macrophage-targeted photosensitiser and a vehicle of phthalocyanine for enhanced photodynamic therapy. Chemical communications. 2017; 53: 4112-5.

71. Shih CM, Cheng SN, Wong CS, Kuo YL, Chou TC. Antiinflammatory and antihyperalgesic activity of C-phycocyanin. Anesthesia and analgesia. 2009; 108: 1303-10.

72. Cherng SC, Cheng SN, Tarn A, Chou TC. Anti-inflammatory activity of c-phycocyanin in lipopolysaccharide-stimulated RAW 264.7 macrophages. Life sciences. 2007; 81: 1431-5.

73. Iijma T, Saitoh N, Nobutomo K, Nambu M, Sakuma K. A prospective cohort study of hepatitis B surface antigen carriers in a working population. Gan. 1984; 75: 571-3.

74. Pattarayan D, Rajarajan D, Ayyanar S, Palanichamy R, Subbiah R. C-phycocyanin suppresses transforming growth factor-beta1-induced epithelial mesenchymal transition in human epithelial cells. Pharmacological reports: PR. 2017; 69: 426-31.

75. Reddy MC, Subhashini J, Mahipal SV, Bhat VB, Srinivas Reddy P, Kiranmai G, et al. C-Phycocyanin, a selective cyclooxygenase-2 inhibitor, induces apoptosis in lipopolysaccharide-stimulated RAW 264.7 macrophages. Biochemical and biophysical research communications. 2003; 304: 385-92.

76. Li B, Zhang X, Gao M, Chu X. Effects of CD59 on antitumoral activities of phycocyanin from Spirulina platensis. Biomedicine \& pharmacotherapy $=$ Biomedecine \& pharmacotherapie. 2005; 59: 551-60.

77. Saini MK, Vaish V, Sanyal SN. Role of cytokines and Jak3/Stat3 signaling in the 1,2-dimethylhydrazine dihydrochloride-induced rat model of colon carcinogenesis: early target in the anticancer strategy. European journal of cancer prevention: the official journal of the European Cancer Prevention Organisation (ECP). 2013; 22: 215-28.

78. Kunte M, Desai K. The Inhibitory Effect of C-phycocyanin Containing Protein Extract (C-PC Extract) on Human Matrix Metalloproteinases (MMP-2 and MMP-9) in Hepatocellular Cancer Cell Line (HepG2). The protein journal. 2017; 36: 186-95

79. Saini MK, Sanyal SN. Targeting angiogenic pathway for chemoprevention of experimental colon cancer using C-phycocyanin as cyclooxygenase-2 inhibitor. Biochemistry and cell biology $=$ Biochimie et biologie cellulaire. 2014; 92: 206-18.

80. Tantirapan P, Suwanwong Y. Anti-proliferative effects of C-phycocyanin on a human leukemic cell line and induction of apoptosis via the PI3K/AKT pathway. Journal of Chemical \& Pharmaceutical Research. 2014; 2014: 1295-301.

81. Liao $\mathrm{G}$, Gao $\mathrm{B}$, Gao $\mathrm{Y}$, Yang $\mathrm{X}$, Cheng $\mathrm{X}$, Ou $\mathrm{Y}$, Phycocyanin Inhibits Tumorigenic Potential of Pancreatic Cancer Cells: Role of Apoptosis and Autophagy. Scientific reports. 2016; 6: 34564

82. Nishanth RP, Ramakrishna BS, Jyotsna RG, Roy KR, Reddy GV, Reddy PK, et al. C-Phycocyanin inhibits MDR1 through reactive oxygen species and cyclooxygenase- 2 mediated pathways in human hepatocellular carcinoma cell line. European journal of pharmacology. 2010; 649: 74-83.

83. Tan W, Lu J, Huang M, Li Y, Chen M, Wu G, et al. Anti-cancer natural products isolated from chinese medicinal herbs. Chinese medicine. 2011; 6: 27.

84. Liu Q, Huang Y, Zhang R, Cai T, Cai Y. Medical Application of Spirulina platensis Derived C-Phycocyanin. Evidence-based complementary and alternative medicine: eCAM. 2016; 2016: 7803846.

85. Fernández-Rojas B, Hernández-Juárez J, Pedraza-Chaverri J. Nutraceutical properties of phycocyanin. Journal of Functional Foods. 2014; 11: 375-92.

86. Naidu KA, Sarada R, Manoj G, Khan MY, Swamy MM, Viswanatha S, et al. Toxicity Assessment Of Phycocyanin - A Blue Colorant From Blue Green Alga Spirulina platensis. Food Biotechnology. 1999; 13: 51-66.

87. Liu $\mathrm{Y}, \mathrm{Xu} \mathrm{L}, \mathrm{Ni} \mathrm{C}$, Lin $\mathrm{L}$, Zhang $\mathrm{C}$. Inhibitory effect of phycocyanin from Spirulina platensis on the growth of human leukemia K562 cells. Journal of Applied Phycology. 2000; 12: 125-30.

88. Ying J, Wang J, Ji H, Lin C, Pan R, Zhou L, et al. Transcriptome analysis of phycocyanin inhibitory effects on SKOV-3 cell proliferation. Gene. 2016; 585: 58-64.

89. Bedner E, Li X, Gorczyca W, Melamed MR, Darzynkiewicz Z. Analysis of apoptosis by laser scanning cytometry. Cytometry. 1999; 35: 181-95.

90. Kaufmann $\mathrm{SH}$, Earnshaw WC. Induction of apoptosis by cancer chemotherapy. Experimental cell research. 2000; 256: 42-9.

91. Creagh EM, Conroy H, Martin SJ. Caspase-activation pathways in apoptosis and immunity. Immunological reviews. 2003; 193: 10-21.

92. Johnson VL, Ko SC, Holmstrom TH, Eriksson JE, Chow SC. Effector caspases are dispensable for the early nuclear morphological changes during chemical-induced apoptosis. Journal of cell science. 2000; 113 (Pt 17): 2941-53.

93. Bharathiraja S, Seo H, Manivasagan P, Santha Moorthy M, Park S, Oh J. In Vitro Photodynamic Effect of Phycocyanin against Breast Cancer Cells. Molecules (Basel, Switzerland). 2016; 21.

94. Basha OM, Hafez RA, El-Ayouty YM, Mahrous KF, Bareedy MH, Salama AM. C-Phycocyanin inhibits cell proliferation and may induce apoptosis in human HepG2 cells. The Egyptian journal of immunology. 2008; 15: 161-7.

95. Pardhasaradhi BV, Ali AM, Kumari AL, Reddanna $\mathrm{P}$, Khar A. Phycocyanin-mediated apoptosis in AK-5 tumor cells involves 
down-regulation of $\mathrm{Bcl}-2$ and generation of ROS. Molecular cancer therapeutics. 2003; 2: 1165-70

96. Li B, Gao MH, Zhang XC, Chu XM. Molecular immune mechanism of C-phycocyanin from Spirulina platensis induces apoptosis in HeLa cells in vitro. Biotechnology and applied biochemistry. 2006; 43: 155-64.

97. Yang F, Li B, Chu XM, Lv CY, Xu YJ, Yang P. Molecular mechanism of inhibitory effects of C-phycocyanin combined with all-trans-retinoic acid on the growth of HeLa cells in vitro. Tumour biology: the journal of the International Society for Oncodevelopmental Biology and Medicine. 2014; 35: 5619-28.

98. Gantar M, Dhandayuthapani S, Rathinavelu A. Phycocyanin induces apoptosis and enhances the effect of topotecan on prostate cell line LNCaP. Journal of medicinal food. 2012; 15: 1091-5.

99. Ying J, Pan RW, Wang MF, Chen JS, Liu Q, Zhang HQ, et al. Effects of phycocyanin on apoptosis of human laryngeal cancer HEP-2 cells. 中国病理生 理杂志. $2015 ; 31$.

100. Pan R, Lu R, Zhang Y, Zhu M, Zhu W, Yang R, et al. Spirulina phycocyanin induces differential protein expression and apoptosis in SKOV-3 cells. International journal of biological macromolecules. 2015; 81: 951-9.

101. Lu W, Yu P, Li J. Induction of apoptosis in human colon carcinoma COLO 205 cells by the recombinant alpha subunit of C-phycocyanin. Biotechnology letters. 2011; 33: 637-44.

102. Braithwaite MC, Tyagi C, Tomar LK, Kumar P, Choonara YE, Pillay V. Nutraceutical-based therapeutics and formulation strategies augmenting their efficiency to complement modern medicine: An overview. Journal of Functional Foods. 2014; 6: 82-99.

103. Saini MK, Vaiphei K, Sanyal SN. Chemoprevention of DMH-induced rat colon carcinoma initiation by combination administration of piroxicam and C-phycocyanin. Molecular and cellular biochemistry. 2012; 361: 217-28.

104. Saini MK, Sanyal SN, Vaiphei K. Piroxicam and C-phycocyanin mediated apoptosis in 1,2-dimethylhydrazine dihydrochloride induced colon carcinogenesis: exploring the mitochondrial pathway. Nutrition and cancer. 2012; 64: 409-18.

105. Saini MK, Sanyal SN. Piroxicam and c-phycocyanin prevent colon carcinogenesis by inhibition of membrane fluidity and canonical Wnt/beta-catenin signaling while up-regulating ligand dependent transcription factor PPARgamma. Biomedicine \& pharmacotherapy = Biomedecine \& pharmacotherapie. 2014; 68: 537-50.

106. Li B, Gao MH, Lv CY, Yang P, Yin QF. Study of the synergistic effects of all-transretinoic acid and C-phycocyanin on the growth and apoptosis of A549 cells. European journal of cancer prevention: the official journal of the European Cancer Prevention Organisation (ECP). 2016; 25: 97-101.

107. Khan M, Varadharaj S, Shobha JC, Naidu MU, Parinandi NL, Kutala VK, et al. C-phycocyanin ameliorates doxorubicin-induced oxidative stress and apoptosis in adult rat cardiomyocytes. Journal of cardiovascular pharmacology. 2006; 47: 9-20.

108. Davis ME, Chen ZG, Shin DM. Nanoparticle therapeutics: an emerging treatment modality for cancer. Nature reviews Drug discovery. 2008; 7: 771-82.

109. Liao X, Zhang X. Preparation, characterization and cytotoxicity of carbon nanotube-chitosan-phycocyanin complex. Nanotechnology. 2012; 23: 035101.

110. Yang P, Li B, Yin QF, Wang YJ. Carboxymethyl chitosan nanoparticles coupled with CD59-specific ligand peptide for targeted delivery of C-phycocyanin to HeLa cells. Tumour biology: the journal of the International Society for Oncodevelopmental Biology and Medicine. 2017; 39: 1010428317692267.

111. Saini MK, Sanyal SN. Piroxicam and c-phycocyanin prevent colon carcinogenesis by inhibition of membrane fluidity and canonical Wnt/ $\beta$-catenin signaling while up-regulating ligand dependent transcription factor PPARy. Biomed Pharmacother. 2014; 68: 537-50.

112. Telliez A, Furman C, Pommery N, Henichart JP. Mechanisms leading to COX-2 expression and COX-2 induced tumorigenesis: topical therapeutic strategies targeting COX-2 expression and activity. Anti-cancer agents in medicinal chemistry. 2006; 6: 187-208.

113. Davies G, Martin LA, Sacks N, Dowsett M. Cyclooxygenase-2 (COX-2), aromatase and breast cancer: a possible role for COX-2 inhibitors in breast cancer chemoprevention. Annals of oncology: official journal of the European Society for Medical Oncology. 2002; 13: 669-78.

114. von Rahden BH, Stein HJ, Puhringer F, Koch I, Langer R, Piontek G, et al. Coexpression of cyclooxygenases (COX-1, COX-2) and vascular endothelial growth factors (VEGF-A, VEGF-C) in esophageal adenocarcinoma. Cancer research. 2005; 65: 5038-44

115. Noda M, Tatsumi Y, Tomizawa M, Takama T, Mitsufuji S, Sugihara H, et al. Effects of etodolac, a selective cyclooxygenase-2 inhibitor, on the expression of E-cadherin-catenin complexes in gastrointestinal cell lines. Journal of gastroenterology. 2002; 37: 896-904.

116. Dohadwala $M$, Yang SC, Luo J, Sharma S, Batra RK, Huang $M$, et al. Cyclooxygenase-2-dependent regulation of E-cadherin: prostaglandin $\mathrm{E}(2)$ induces transcriptional repressors ZEB1 and snail in non-small cell lung cancer. Cancer research. 2006; 66: 5338-45.

117. Shintani T, Klionsky DJ. Autophagy in health and disease: a double-edged sword. Science (New York, NY). 2004; 306: 990-5.

118. White E, DiPaola RS. The double-edged sword of autophagy modulation in cancer. Clinical cancer research: an official journal of the American Association for Cancer Research. 2009; 15: 5308-16.

119. Hoare M, Young AR, Narita M. Autophagy in cancer: having your cake and eating it. Seminars in cancer biology. 2011; 21: 397-404.
120. Shen HM, Codogno P. Autophagic cell death: Loch Ness monster or endangered species? Autophagy. 2011; 7: 457-65

121. Denton D, Nicolson S, Kumar S. Cell death by autophagy: facts and apparent artefacts. Cell death and differentiation. 2012; 19: 87-95.

122. Giansanti V, Tillhon M, Mazzini G, Prosperi E, Lombardi P, Scovassi AI. Killing of tumor cells: a drama in two acts. Biochemical pharmacology. 2011; 82: $1304-10$

123. Gump JM, Thorburn A. Autophagy and apoptosis: what is the connection? Trends in cell biology. 2011; 21: 387-92.

124. Maiuri MC, Zalckvar E, Kimchi A, Kroemer G. Self-eating and self-killing: crosstalk between autophagy and apoptosis. Nature reviews Molecular cell biology. 2007; 8: 741-52

125. Wang L, Gao C, Yao S, Xie B. Blocking autophagic flux enhances matrine-induced apoptosis in human hepatoma cells. International journal of molecular sciences. 2013; 14: 23212-30.

126. Hu C, Zou MJ, Zhao L, Lu N, Sun YJ, Gou SH, et al. E Platinum, a newly synthesized platinum compound, induces autophagy via inhibiting phosphorylation of mTOR in gastric carcinoma BGC-823 cells. Toxicology letters. 2012; 210: 78-86.

127. Mujumdar N, Mackenzie TN, Dudeja V, Chugh R, Antonoff MB, Borja-Cacho $\mathrm{D}$, et al. Triptolide induces cell death in pancreatic cancer cells by apoptotic and autophagic pathways. Gastroenterology. 2010; 139: 598-608.

128. Aoki H, Takada Y, Kondo S, Sawaya R, Aggarwal BB, Kondo Y. Evidence that curcumin suppresses the growth of malignant gliomas in vitro and in vivo through induction of autophagy: role of Akt and extracellular signal-regulated kinase signaling pathways. Molecular pharmacology. 2007; 72: 29-39.

129. Hahn-Windgassen A, Nogueira V, Chen CC, Skeen JE, Sonenberg N, Hay N. Akt activates the mammalian target of rapamycin by regulating cellular ATP level and AMPK activity. The Journal of biological chemistry. 2005; 280: 32081-9.

130. Jung $\mathrm{CH}$, Ro $\mathrm{SH}$, Cao J, Otto NM, Kim DH. mTOR regulation of autophagy. FEBS letters. 2010; 584: 1287-95.

131. Degtyarev M, De Maziere A, Orr C, Lin J, Lee BB, Tien JY, et al. Akt inhibition promotes autophagy and sensitizes PTEN-null tumors to lysosomotropic agents. The Journal of cell biology. 2008; 183: 101-16.

132. Kim KW, Mutter RW, Cao C, Albert JM, Freeman M, Hallahan DE, et al. Autophagy for cancer therapy through inhibition of pro-apoptotic proteins and mammalian target of rapamycin signaling. The Journal of biological chemistry. 2006; 281: 36883-90.

133. Rubinstein AD, Kimchi A. Life in the balance - a mechanistic view of the crosstalk between autophagy and apoptosis. Journal of cell science. 2012; 125: 5259-68.

134. Thorburn A. Apoptosis and autophagy: regulatory connections between two supposedly different processes. Apoptosis: an international journal on programmed cell death. 2008; 13: 1-9.

135. Brummelkamp TR, Nijman SM, Dirac AM, Bernards R. Loss of the cylindromatosis tumour suppressor inhibits apoptosis by activating NF-kappaB. Nature. 2003; 424: 797-801.

136. Javelaud D, Besancon F. NF-kappa B activation results in rapid inactivation of JNK in TNF alpha-treated Ewing sarcoma cells: a mechanism for the anti-apoptotic effect of NF-kappa B. Oncogene. 2001; 20: 4365-72.

137. Schlottmann S, Buback F, Stahl B, Meierhenrich R, Walter P, Georgieff M, et al. Prolonged classical NF-kappaB activation prevents autophagy upon E. coli stimulation in vitro: a potential resolving mechanism of inflammation. Mediators of inflammation. 2008; 2008: 725854

138. Hwang J, Lee HJ, Lee WH, Suk K. NF-kappaB as a common signaling pathway in ganglioside-induced autophagic cell death and activation of astrocytes. Journal of neuroimmunology. 2010; 226: 66-72.

139. Trocoli A, Djavaheri-Mergny M. The complex interplay between autophagy and NF-kappaB signaling pathways in cancer cells. American journal of cancer research. 2011; 1: 629-49.

140. Criollo A, Senovilla L, Authier H, Maiuri MC, Morselli E, Vitale I, et al. The IKK complex contributes to the induction of autophagy. The EMBO journal. 2010; 29: 619-31.

141. Copetti T, Bertoli C, Dalla E, Demarchi F, Schneider C. p65/RelA modulates BECN1 transcription and autophagy. Molecular and cellular biology. 2009; 29: 2594-608. 